\title{
The perils of privatization
}

\section{London}

IT seemed too good to be true. In the spring of 1988, then Prime Minister Margaret Thatcher announced plans to extend her administration's strategy of privatizing state-run enterprise by splitting off the national electric utility into four competing companies. This, it was argued, would lower prices while retaining the utility's large environmental and nuclear research effort, thanks to a disproportionate division of assets that would leave one of the companies National Power - wealthy enough to invest in such long-term projects.

\section{IMAGE \\ UNAVAILABLE FOR COPYRIGHT REASONS}

energy spokesman Rhodri Morgan, John Baker, the head of National Power, explained that the company did not intend to maintain "research programmes which were addressed to the solution of national problems or dealing with national or international issues where these extend far beyond the boundaries of our own company interests." In short, $\mathrm{Na}$ tional Power wants to cut any research that does not directly help its cause, even if it is of national importance. Research in the public interest is for the government to do, say company officials, not them.

So what went wrong? Ultimately, the government's desire for real competition in the electric industry sealed the fate of the research. Unlike previously privatized industries such as British Gas and the water utilities, which were all essentially given monopolies when they were sold, the electric utilities were purposely set up to fight for customers. The competition is even closer than originally intended. Although Thatcher wanted Na-

No place for research: profit rules the power plants.

Three years later, after a last-minute compromise with parliament that stripped National Power of much of its advantage, it is clear that Thatcher's privatization plan was, indeed, too good to be true. The utilities are now in fierce rivalry and National Power has announced its intention to cut its overheads by a half in an effort to reduce costs and remain competitive. Although officials will not reveal the details, company scientists say that National Power is preparing to dismantle most of the $£ 26$ million in non-nuclear research that it inherited from the Central Electric Generating Board, as the electric utilities were collectively known when they were under the government's wing.

Scientists at National Power's Leatherhead laboratory say that all but about 50 to 70 members of the 500 -person research staff will be laid off later this year, and that the remainder will be transferred to the company's Swindon offices. This will effectively mean the end of one of the world's largest acid rain teams, as well as those teams that researched other environmental effects of coal-fired electricity generating plants, from sulphur dioxide to ground-level ozone. Other groups that expect to be eliminated include a superconductivity team and researchers who study the effects of power plants on the nearby bodies of water that serve as source and dump for coolant.

In a letter in June to Labour Party tional Power to take over the nuclear power industry and run it privately (which would have given the company some 70 per cent of the UK energy market), parliament forced her to choose between privatization and expansion of nuclear power. She chose privatization, and returned nuclear power to the government, leaving National Power with a slim 20 per cent lead over the secondlargest privatized utility, Powergen.

"We had no idea that National Power would be shrunk so quickly and shorn of the mindset that it was operating for the public good," says Morgan. Under stockholder pressure to trim costs, National Power has acquired an "overwhelming desire to demonstrate that they can be more private sector than the private sector," he says. "In something as environmentally sensitive as electricity generation, this is a real mistake."

Anticipating that the new battle lines would put a premium on rock-bottom pricing - to the probable detriment of research - parliament inserted a clause in the 1989 privatization act that gave the secretary of state the power to direct the utilities to do research "in the public interest", says Morgan, who helped to write the legislation. "The 'acid rain test' is whether the secretary of state actually uses the provision. We'll ask him to, but he'll probably fight like hell."

So far there are no signs that the government intends to intervene. Mor- gan says that is because National Power has not officially announced the specifics of its cuts yet. But others expect little action even after the cuts are enumerated.

"It's almost impossible to define a 'national interest', especially when it comes to science," says Robert Preddie, a former engineering director at the Central Electric Generating Board and a member of the independent Institute of Energy. "This government's interest in research is minimal - the issue wouldn't even get to square one."

Just how much the government cares about what was once its 'national interest' energy and environment research will be put to the test this autumn, when the House of Commons plans to hold an Energy Select Committee inquiry on the consequence of the electricity privatization. Research - and the lack thereof is expect to be a major topic.

Christopher Anderson

\section{ENVIRONMENT}

\section{Europe's green thumb firmly on nose}

\section{London}

Member states were caught violating European Communities (EC) environmental law almost 170 times last year, 66 per cent more than the year before and more evidence that the Communities' environmental legislation is widely flouted by its members (see Nature 352, 183; 18 July 1991). Of the total of 167 violations, 131 were for a failure of the member states to pass national legislation in conformance with EC dictate, almost three times the previous year's figure, according to a report released last week. But EC officials explain the soaring rate as a sign not of decreasing compliance but of increasing vigilance of regulators in tracking down and prosecuting offenders.

Of the identified cases of violation, only 39 resulted in formal legal proceedings; the rest were just letters of warning. But that is still some 53 per cent more than in the previous year and the highest level of the decade. Of last year's cases, only 16 (down five from 1989) reached the European Court, a sign that member states are beginning to back down when challenged.

To speed the trend, EC officials are beginning to use reports such as this one to shame countries into compliance. In recent years, the EC has taken to publishing community-wide data books, partly as a way to embarrass the countries that refuse to submit their own measurements. Last year, an EC report on bathing water data had nothing but blank pages where Germany and Greece should have been, which - after some media outrage - prompted those countries to institute reforms.

Christopher Anderson 